\title{
Global Budget and Distribution of Peroxyacetyl Nitrate (PAN) for Present and Preindustrial Scenarios
}

\author{
M. Anwar H. Khan ${ }^{1}$, Michael C. Cooke ${ }^{1, a}$, Steven R. Utembe ${ }^{1, b}$, Alexander T. Archibald ${ }^{1, c,}$ Richard G. Derwent $^{2}$, Michael E. \\ Jenkin $^{1,3}$, Kimberley E. Leather ${ }^{4}$, Carl J. Percival ${ }^{4}$ and Dudley E. Shallcross ${ }^{1, *}$ \\ ${ }^{1}$ Atmospheric Chemistry Research Group, School of Chemistry, University of Bristol, Cantock's Close, Bristol BS8 1TS, UK \\ ${ }^{2}$ rdscientific, Newbury, Berkshire, UK \\ ${ }^{3}$ Atmospheric Chemistry Services, Okehampton, Devon, EX20 4QB, UK \\ ${ }^{4}$ The Centre for Atmospheric Science, The School of Earth, Atmospheric and Environmental Science, The University of Manchester, Brunswick \\ Street, Manchester, M13 9PL, UK \\ ${ }^{a}$ Now at the Met Office, FitzRoy Road, Exeter, Devon, EX1 3PB, UK \\ ${ }^{b}$ Now at the School of Earth Sciences, University of Melbourne, Parkville VIC 3010, Australia \\ ${ }^{c}$ Now at the NCAS-Climate and the Centre for Atmospheric Science, University of Cambridge, Cambridge, UK
}

\section{Abstract}

\section{Publication History:}

A global 3-D chemistry and transport model, STOCHEM integrated with a detailed VOC oxidation scheme (CRI v2-R5) has been employed to study the important $\mathrm{NO}_{\mathrm{x}}$ reservoir compound, peroxyacetyl nitrate (PAN). Globally, PAN is produced entirely by the reaction of acetyl peroxy radicals $\left(\mathrm{CH}_{3} \mathrm{CO}_{3}\right)$ with $\mathrm{NO}_{2}$ and up to $2.0 \mathrm{ppb}$ of PAN is found over the polluted regions of North America during JuneJuly-August for the present scenario. The imbalances between model and measurement data are noted, with STOCHEM-CRI overestimating PAN mixing ratios relative to the measurement data by +17 and $+80 \mathrm{pptv}$ for the lower and upper troposphere, respectively. The inclusion of additional $\mathrm{HO}_{\mathrm{x}}$ recycling mechanisms (e.g. related to isoprene oxidation) in STOCHEM-CRI causes a decrease in PAN in a present scenario by as much as $40 \%$ over sink regions and reduces the model-measurement disagreement by $90 \%$ for the lower troposphere and $40 \%$ for the upper troposphere. The lower $\mathrm{NO}_{\mathrm{x}}$ emissions and $\mathrm{CH}_{3} \mathrm{CO}_{3}$ formation upon including $\mathrm{HO}_{\mathrm{x}}$ recycling in a preindustrial scenario led to a decrease in PAN formation by as much as $40 \%$. The decrease in PAN formation results in less nitrogen being transported to remote regions which in turn leads to the greatest percentage change in $\mathrm{O}_{3}$ concentration ( $9 \%$ decrease) in the equatorial regions.

\section{Introduction}

Peroxyacetyl nitrate (PAN) is formed via the oxidation or photolysis of oxygenated volatile organic compounds (oVOCs) in the presence of $\mathrm{NO}_{2}$ [1-2]. PAN is phytotoxic in high concentrations [3-4], and is a powerful lachrymator formed in photochemical air pollution [5-6]. It can allow $\mathrm{NO}_{x}$ to be sequestered and transported over long distances and then be released under high temperature conditions (lower troposphere) resulting in the production of ozone $\left(\mathrm{O}_{3}\right)$ as well as hydroxyl radicals $(\mathrm{OH})$ in remote regions [7-15]. The atmospheric loss for PAN is predominantly from thermal decomposition [16-19] because of its small photolysis rate [20], slow reaction with $\mathrm{OH}[20$ $21]$, and low wet deposition rate [22-23].

PAN has no known direct emission sources and is therefore an excellent indicator of the photochemical processing of an air mass which plays a significant role in the atmospheric transport of reactive nitrogen on a regional and global scale. Quantification of the spatial distribution of PAN and its global budget can be a useful tool in determining the oxidative reactions involved in the formation of $\mathrm{O}_{3}$ as well as other secondary air pollutants (e.g. nitric acid). In spite of its importance in the chemical processing of the troposphere, there are numerous measurements of PAN from different urban and remote areas [11,24-53], but these measurements are sparse both in space and time. The measurements of the temporal variability of PAN are necessary to evaluate the global budget of $\mathrm{O}_{3}, \mathrm{NO}_{\mathrm{y}}, \mathrm{HO}_{\mathrm{x}}$, and the associated recycling of $\mathrm{NO}_{\mathrm{x}}$. Thus, we present the global burden and the global distribution of PAN from the STOCHEM-CRI global chemistry transport model. We compare STOCHEM model results with a wide range of observations of PAN from the flight data set compiled by Emmons et al. [54], Horowitz et al. [55], and Fischer et al. [56] and twenty individual field campaign data set. The effects of additional $\mathrm{HO}_{\mathrm{x}}$ recycling mechanisms involving isomerisation of isoprene-derived peroxy radicals [57] and propagating channels for the reactions of $\mathrm{HO}_{2}$ with acyl peroxy radicals, $\mathrm{RCO}_{3}$ [58] in both present and preindustrial scenarios are shown in the study.

\section{Methods}

\section{Model description}

STOCHEM is a global 3-dimensional tropospheric chemistry transport model that adopts a Lagrangian approach splitting the troposphere into 50,000 constant mass air parcels which are advected by meteorological data from the UKMO Hadley Centre global general circulation model called the Unified Model (UM). The Lagrangian cells are based on a grid resolution of $1.25^{\circ}$ longitude, $0.8333^{\circ}$ latitude, and 12 unevenly spaced (with respect to altitude) vertical levels between the surface and an upper boundary of $100 \mathrm{hPa}$ [59-60]. The resulting simulated concentrations are mapped onto an Eulerian "Corresponding Author: Dr. Dudley E. Shallcross, Atmospheric Chemistry Research Group, School of Chemistry, University of Bristol, Cantock's Close, Bristol BS8 1TS, United Kingdom; E-mail: d.e.shallcross@bristol.ac.uk

Citation: Khan MAH, Cooke MC, Utembe SR, Archibald AT, Derwent RG, et al. (2017) Global Budget and Distribution of Peroxyacetyl Nitrate (PAN) for Present and Preindustrial Scenarios. Int J Earth Environ Sci 2: 130. doi: https://doi. org/10.15344/2456-351X/2017/130

Copyright: @ 2017 Khan et al. This is an open-access article distributed under the terms of the Creative Commons Attribution License, which permits unrestricted use, distribution, and reproduction in any medium, provided the original author and source are credited. 
grid resolution of $5^{\circ}$ by $5^{\circ}$ with 9 equally vertically spaced pressure levels, each $100 \mathrm{hPa}$ thick. A detailed description of the dispersion processes including the vertical coordinate, advection scheme used in STOCHEM can be found in Collins et al. [59] with updates described by Derwent et al. [61].

The STOCHEM-CRI model utilises the Common Representative Intermediates version 2 and reduction 5 chemical mechanism. The CRI v2-R5 was built using a series of five-day box model simulations on each species, on a compound-by-compound basis. The performance of the chemistry of these simulations was optimised using the Master Chemical Mechanism (MCM) with $\mathrm{O}_{3}$ production being the primary criterion [62]. Simulations completed over a range of $32 \mathrm{VOC} / \mathrm{NO}$ ratios by CRI v2-R5 have shown compelling agreement with MCM v3.1 for ozone and other radical and closed-shell species (including PAN), hence establishing it as an appropriate reference mechanism for the use in global chemistry transport models [63-64]. The details of the CRI v2-R5 mechanism is given by Jenkin et al. [65], Watson et al. [64], and Utembe et al. [66] with updates highlighted in Utembe et al. [60]. The emissions data employed in the base case STOCHEM model were adapted from the Precursor of $\mathrm{O}_{3}$ and their Effects in the Troposphere (POET) inventory [67] for the year 1998. More details about the global emission data used in the STOCHEM can be found in Khan et al. [68].

The additional $\mathrm{HO}_{x}$ recycling mechanisms involving isomerisation of isoprene-derived peroxy radicals $[57,69-70]$ and the propagating channels for the reactions of acyl peroxy radicals with $\mathrm{HO}_{2}$ [58] have been introduced into the STOCHEM-CRI. In isoprene induced $\mathrm{HO}_{x}$ recycling mechanism, the intermolecular rearrangements of isoprene derived alkyl peroxy radicals were sufficiently rapid to compete with biomolecular routes leading to two additional oxidation pathways of the alkyl peroxy radicals at low $\mathrm{NO}_{\mathrm{x}}$ levels. The two additional pathways involve 1,5-H-shift resulting in $\mathrm{OH}, \mathrm{HCHO}$ and methyl vinyl ketone (MVK) or methacrolein (MACR) formation; and 1,6-H-shift leading to the formation of $\mathrm{HO}_{2}$ and a hydroperoxyaldehyde (HPALD), which is removed predominantly by rapid photolysis to generate additional $\mathrm{OH}$ and other radical products.

Two experiments were conducted as the base case reference run referred to as 'Base' described in Utembe et al. [60] and a model including the isoprene $\mathrm{HO}_{\mathrm{x}}$ recycling and radical propagation in a simulation referred to as 'ISOP'. Two further experiments (referred to as 'B1800' and 'ISOP1800') were performed for a preindustrial scenario described in Khan et al. [71]. All simulations were conducted with meteorology from 1998 for a period of 24 months with the first 12 allowing the model to spin up. Analysis is performed on the subsequent 12 months of data.

\section{Results}

The global burden of PAN for the present scenario and the $\mathrm{HO}_{\mathrm{x}}$ recycling impact on its burden

In the model, PAN is produced entirely from the reaction of acetyl peroxy radicals $\left(\mathrm{CH}_{3} \mathrm{CO}_{3}\right)$ with $\mathrm{NO}_{2}$. The formation of $\mathrm{CH}_{3} \mathrm{CO}_{3}$ from a suite of VOC oxidation processes are summarized in Appendix A. The greater input of the organic materials and the greater complexity of the chemistry scheme in the CRI v2-R5 mechanism of the STOCHEM model [60], leads to a global burden of $398 \mathrm{Gg}(\mathrm{N})$ PAN for the present scenario. The globally averaged tropospheric lifetimes of PAN is found to be 9.3 hours, the value being close to those reported by Singh [9], and Roberts et al. [42]. The $\mathrm{HO}_{\mathrm{x}}$ recycling mechanism employed in the STOCHEM-CRI gives consistent results with the box model simulations in Archibald et al. [69] and with the parameterized representations of Lelieveld et al. [72] and Pugh et al. [73]. The reduced total PAN global burden $(346 \mathrm{Gg}(\mathrm{N}))$ in the study are driven by the decreased production of $\mathrm{CH}_{3} \mathrm{CO}_{3}$ (e.g. $11 \%$ less $\mathrm{CH}_{3} \mathrm{CO}_{3}$ production in the ISOP scenario compared with the base case scenario) leading to the global decrease of PAN by $13 \%$ for the present scenario which given that the base simulation generally over-predicts PAN brings the model into closer agreement with measured values. However, the concentrations of $\mathrm{CH}_{3} \mathrm{CO}_{3}$ molecules is a balance between faster production via VOC oxidation and faster removal via reaction with $\mathrm{HO}_{2}, \mathrm{NO}, \mathrm{NO}_{3}$ and partitioning into PAN species [74]. The inclusion of $\mathrm{HO}_{x}$ recycling mechanisms leads to a slight decrease in the tropospheric lifetime of PAN (9.0 hours).

\section{Surface and zonal distribution of PAN for the present scenario}

The annual mean surface and zonal distribution of PAN from STOCHEM-CRI and their comparison with STOCHEM-ISOP for the present scenario are shown in Figure 1 and Figure 2, respectively. The surface distribution of PAN is driven by the location of $\mathrm{NO}$ and VOC emissions. Biomass burning and vegetation emissions of $\mathrm{NO}_{\mathrm{x}}(15 \mathrm{Tg}$ $(\mathrm{N}) / \mathrm{yr})$ are located in forested regions. Anthropogenic emissions of $\mathrm{NO}_{\mathrm{x}}$ are predominantly distributed over North America, central Europe and South East Asia with a total emissions of $31 \mathrm{Tg}(\mathrm{N}) / \mathrm{yr}$. During June-July-August (J-J-A), the concentrations of PAN are found in between 0.7 to 1.0 ppbv over the continents (Figure 1a). Air masses containing high NOx mixing ratios and high levels of VOCs favour PAN production over the continents with a maximum of 2.0 ppbv over the polluted regions of North America (Figure 1a). During December-January-February (D-J-F) and J-J-A, the mixing ratio of PAN is found to be up to $1.2 \mathrm{ppbv}$ over the forested regions near the equator (Figure 1a and Figure 1b). The increased biomass burning activity and formation from the degradation chemistry of both isoprene and monoterpenes in STOCHEM-CRI [60] lead to more PAN formation over forested regions. The more complex mechanism in STOCHEM-CRI shows the importance of PAN especially from isoprene and continued work in improving measurement techniques, increasing the amount of measurements and improving mechanistic understanding is essential. The inclusion of $\mathrm{HO}_{\mathrm{x}}$ recycling leads to an increase of PAN over source regions by as much as $10 \%$ and a decrease of PAN over sink regions by as much as $40 \%$ (Figure $1 \mathrm{c}$ and Figure 1d).

The zonal mean of PAN for STOCHEM-CRI shows its highest level between $50^{\circ} \mathrm{N}-90^{\circ} \mathrm{N}$ during J-J-A (up to $0.5 \mathrm{ppb}$ ) at $300-600 \mathrm{hPa}$ and between $10^{\circ} \mathrm{S}-5^{\circ} \mathrm{S}$ during D-J-F (up to $0.4 \mathrm{ppb}$ ) at $300-500 \mathrm{hPa}$ (Figure $2 \mathrm{a}$ and Figure $2 \mathrm{~b}$ ). These high levels of PAN are related predominantly to anthropogenic activity between $30^{\circ} \mathrm{N}$ and $60^{\circ} \mathrm{N}$ and the result of vegetative and biomass burning activity over the tropics. The high levels of PAN at the top of the model domain are found because of the upward transport from PAN production regions as well as the less significant removal process (e.g. thermal decomposition) in the upper troposphere with the lower temperatures encountered. The maximum PAN levels in the region of $50^{\circ} \mathrm{N}-90^{\circ} \mathrm{N}$ during J-J-A at the middle to upper tropospheric region in this study (Figure 2a) is consistent with the global modelling results from the GEOS-Chem model presented by Fischer et al. [56] which indicates the highest PAN concentrations at $4-10 \mathrm{~km}$ in the region of $30-60^{\circ} \mathrm{N}$ in J-J-A. The inclusion of $\mathrm{HO}_{x}$ recycling leads to a decrease of PAN by up to $30 \%$ in the tropics (during J-J-A) and in the remote $\mathrm{SH}$ regions (during D-J-F) (Figure $2 \mathrm{c}$ and Figure $2 \mathrm{~d}$ ) due to the decreased productions of $\mathrm{CH}_{3} \mathrm{CO}_{3}$. 
Citation: Khan MAH, Cooke MC, Utembe SR, Archibald AT, Derwent RG, et al. (2017) Global Budget and Distribution of Peroxyacetyl Nitrate (PAN) for Present and Preindustrial Scenarios. Int J Earth Environ Sci 2: 130. doi: https://doi.org/10.15344/2456-351X/2017/130
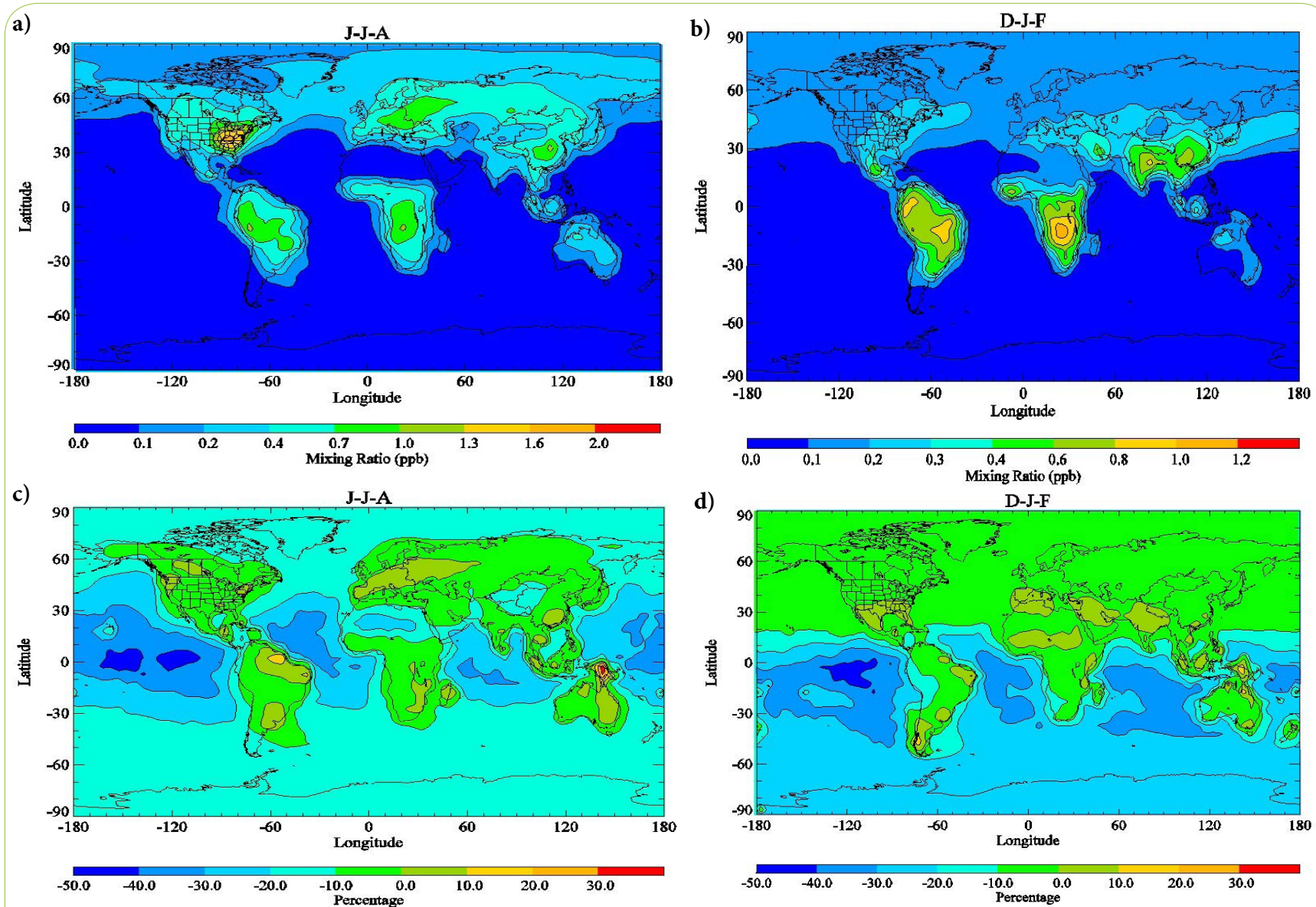

Figure 1: The surface level distribution of PAN for the present scenario during (a) June-July-August (J-J-A), (b) December-January-February (D-J-F).

The percentage changes of surface PAN between the base run and isoprene HOx recycling during (c) J-J-A, (d) D-J-F. (Note: Percentage change =

(STOCHEM-ISOP - STOCHEM-base) ${ }^{\star} 100 /$ STOCHEM-base)

\section{Model-measurement comparison}

The data compilation of Emmons et al. [54], Horowitz et al. [55], and Fischer et al. [56] containing measurements of PAN from a selection of aircraft campaigns (see Appendix B for more details) produced a set of data representing a broad distribution of regions throughout the troposphere which was used to compare with the modelled PAN in order to evaluate model performance (Figure 3 ). The CRI mechanism in STOCHEM over-predicts the upper tropospheric PAN substantially for most of the locations relative to the measured data. Similar results were found in the global modelling results from the MATCH v3 model showed by von Kuhlmann et al. [75] in where the model over-predicted PAN in the remote troposphere and more often at higher altitudes. In general, PAN concentrations increase with altitude in the troposphere because of the increased thermochemical stability in the cold upper troposphere. The differences between average modelled and observed PAN concentrations for all locations referred to by mean biases are found to be +17 and +80 pptv for the lower troposphere $(\sim 0-4 \mathrm{~km})$ and upper troposphere $(\sim 6-12 \mathrm{~km})$, respectively.

The increases in PAN in our study are driven by an increase of the $\mathrm{CH}_{3} \mathrm{CO}_{3}$ (which is the precursor radical) due to the increased complexity of the emitted VOC speciation represented in STOCHEMCRI. Among all of the campaigns, the regions dominated by vegetation and biomass burning emissions (e.g. TRACE-A) have higher PAN levels and the model PAN in the bottom five levels (up to $5 \mathrm{~km}$ ) fit reasonably well with the measured mean. The over-prediction of PAN in the upper troposphere could be due to the higher abundances of $\mathrm{CH}_{3} \mathrm{CO}_{3}$ in the STOCHEM-CRI model, which are ubiquitously distributed throughout the troposphere because of its formation during the oxidation of most NMVOCs [76]. PEM-Tropics A was a campaign to investigate the effect of biomass burning on the $\mathrm{NO}$ species in the remote Pacific during September and October. Fiji, Tahiti and Christmas Island belongs in the PEM-Tropics campaign region where there is a good overall agreement between model and measurements. However there are large overestimations of model PAN in Fiji and Hawaii during the PEM-Tropics B campaign which was performed during March-April with minor biomass burning effects. This could indicate that convection in the model transports $\mathrm{CH}_{3} \mathrm{CO}_{3}$ precursors into the higher altitudes where PAN is formed with a longer life-time during March-April. The model mean PAN fit well within one standard deviation of the measured mean over Japan (Trace-P) where there were periods of clean air from the Pacific and Asian outflow. The model mean PAN also produces good agreement with measurements at Labrador (A3B), Mexico (MILAGRO), Eastern North America (INTEX-A) and worse agreement at Ireland (SONEX), Greenland (POLARCAT), North American Arctic (ARCTAS), East coast Japan (PWA and PWB), north Pacific (PWA), and Philippine sea $(\mathrm{PWB})$ in where the model overestimates PAN in the upper troposphere by a factor of 2-3. The overestimate of PAN in the regions may be due to the higher abundances of $\mathrm{CH}_{3} \mathrm{CO}_{3}$ precursors, high $\mathrm{NO}_{\mathrm{x}}$ concentrations in the main source regions for PAN, lightning, and uncertainties of the formation or decomposition rate of PAN. 
Citation: Khan MAH, Cooke MC, Utembe SR, Archibald AT, Derwent RG, et al. (2017) Global Budget and Distribution of Peroxyacetyl Nitrate (PAN) for Present and Preindustrial Scenarios. Int J Earth Environ Sci 2: 130. doi: https://doi.org/10.15344/2456-351X/2017/130
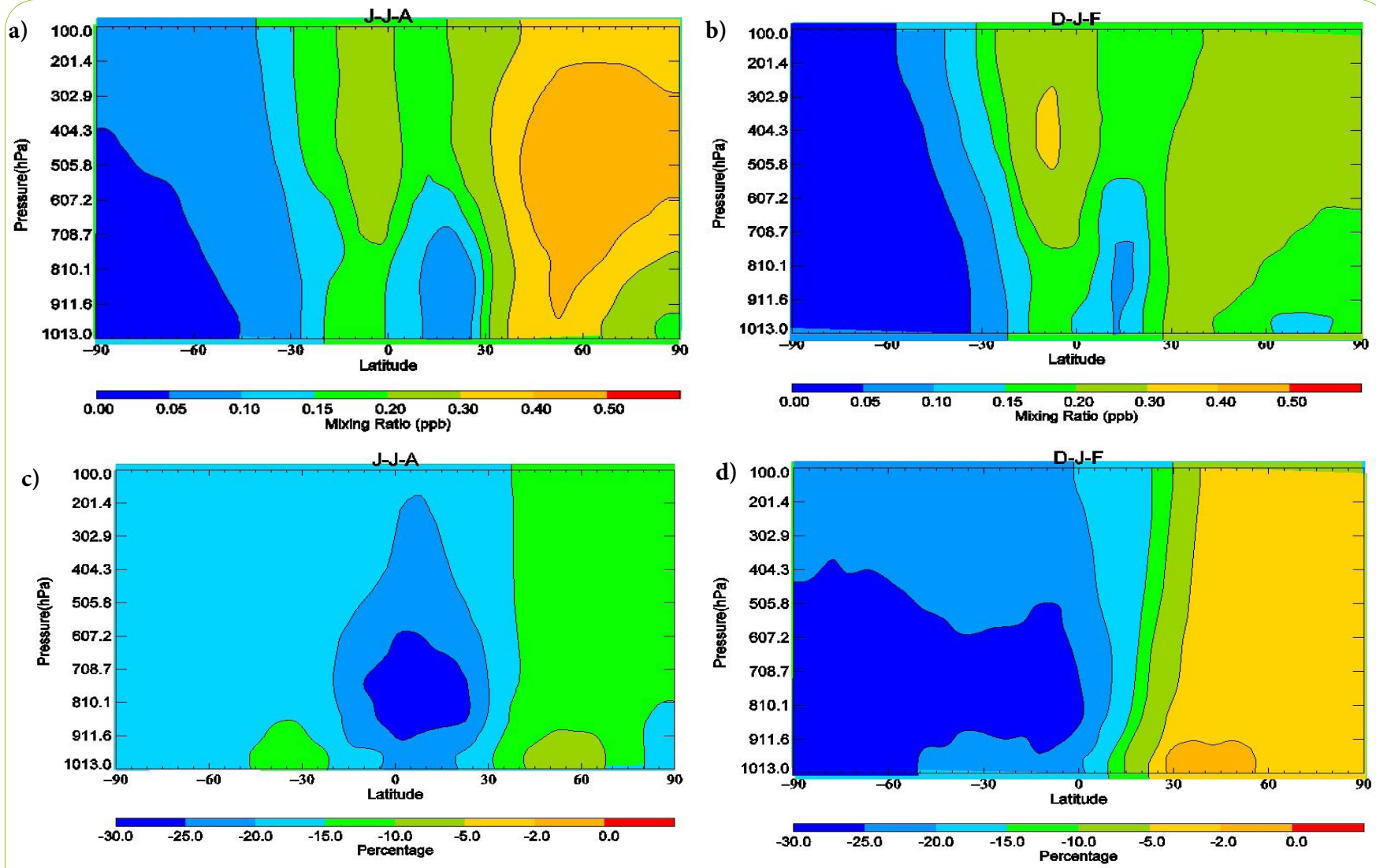

Figure 2: The zonal level distribution of PAN for the present scenario during (a) J-J-A, (b) D-J-F. The percentage changes of zonal PAN between the base run and isoprene HOx recycling during (c) J-J-A, (d) D-J-F. (Note: Percentage change $=\left(\right.$ STOCHEM-ISOP - STOCHEM-base) ${ }^{*} 100 /$ STOCHEM-base).

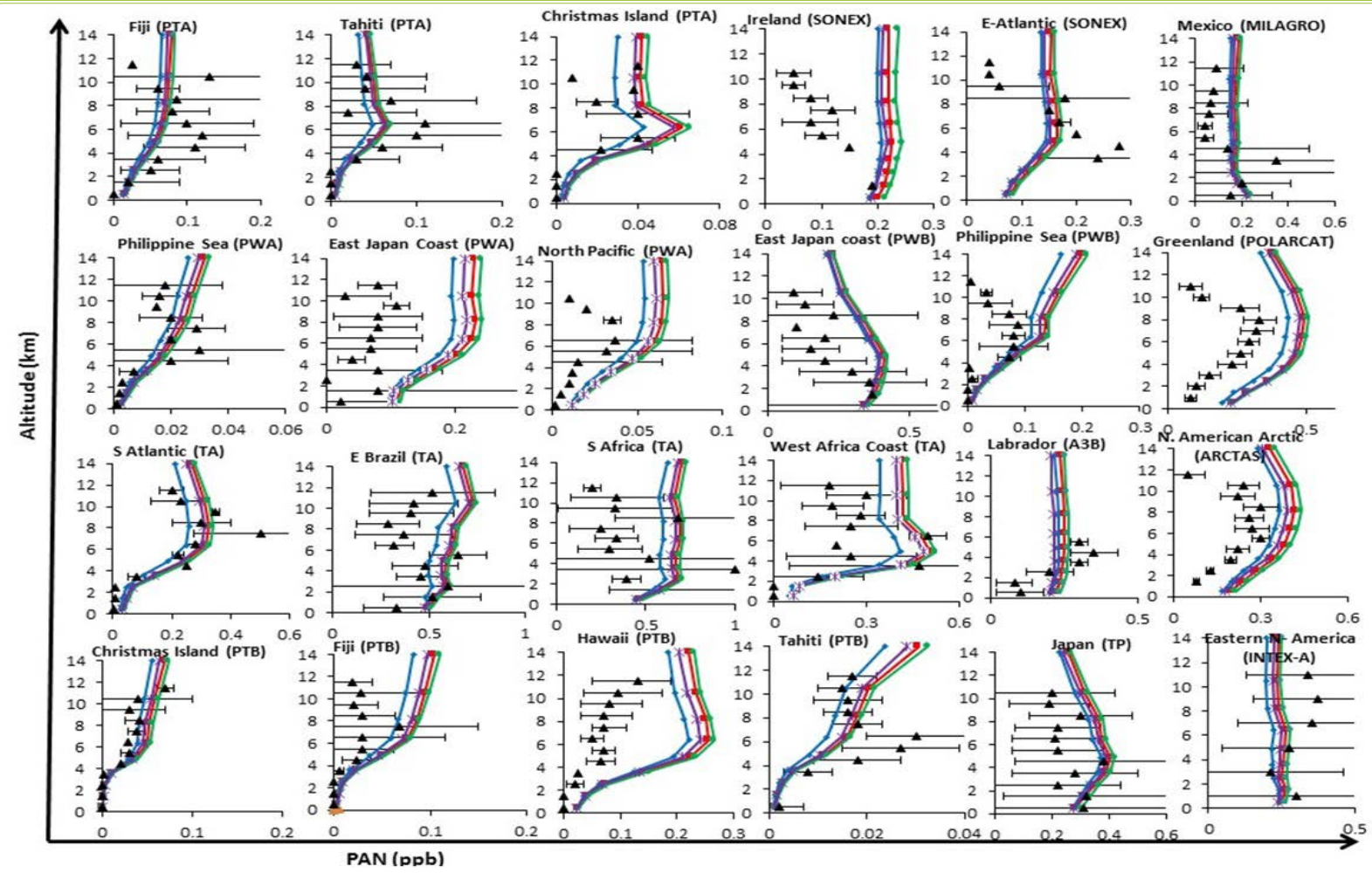

Figure 3: Vertical profiles for measured and modelled PAN, using the aircraft measurement and the STOCHEM-CRI calculations. Red, blue, green, and violet lines represent mean calculated values of PAN produced by the STOCHEM-base, the STOCHEM-ISOP, the STOCHEM-HIGHK, and the STOCHEM-LOWK respectively. Black triangles represent the measurement PAN data and the black error bars represent measurement variability. 
Citation: Khan MAH, Cooke MC, Utembe SR, Archibald AT, Derwent RG, et al. (2017) Global Budget and Distribution of Peroxyacetyl Nitrate (PAN) for Present and Preindustrial Scenarios. Int J Earth Environ Sci 2: 130. doi: https://doi.org/10.15344/2456-351X/2017/130

Page 5 of 10

The $\mathrm{HO}_{\mathrm{x}}$ recycling caused an increase in $\mathrm{OH}$, reducing the lifetimes of NMVOCs resulting in a decrease in $\mathrm{CH}_{3} \mathrm{CO}_{3}$ concentrations to produce PAN at the free troposphere, which has improved agreement with measurements for most of the locations. The mean biases from measurements are reduced by $90 \%$ and $40 \%$ for the lower troposphere and upper troposphere, respectively upon addition of $\mathrm{HO}_{\mathrm{x}}$ recycling in STOCHEM-CRI.

The rate coefficient of the temperature dependent PAN formation used in the STOCHEM-CRI model $\left(\mathrm{k}_{0}=2.7 \times 10^{-28}(\mathrm{~T} / 300)-7.1 \mathrm{~cm}^{6}\right.$ molecule $\mathrm{e}^{-2} \mathrm{~s}^{-1}$ and $\mathrm{k}=12.1 \times 10^{-12}(\mathrm{~T} / 300)^{-0.9} \mathrm{~cm}^{3}$ molecule $\left.{ }^{-1} \mathrm{~s}^{-1}\right)$ were subsequently perturbed upwards and downwards by considering the uncertainties of the rate coefficients. Therefore, two more simulations were performed with two sets of different PAN formation rates deviating $\mathrm{k}_{0}$ by $\pm 50 \%$ and $\mathrm{k}_{\infty}$ by $\pm 15 \%$ from the unperturbed run with a high rate coefficient referred as "STOCHEM-HIGHK" and with low rate coefficient referred as "STOCHEM-LOWK". The STOCHEM-HIGHK run shows the average increase of PAN mixing ratios in the lower and upper troposphere by $6 \%$ and $4 \%$, respectively. In the STOCHEM-LOWK run, the overestimate of the average model PAN for all campaign sites is reduced by $5 \%$ and $7 \%$ at the lower and upper troposphere, respectively, but the decrease of PAN mixing ratios with altitude above $\sim 6 \mathrm{~km}$ is not large enough to decrease the discrepancy of the model-measurement PAN data especially in the upper troposphere.
Twenty surface measurement campaigns have been compiled to form a dataset of PAN (more details in Appendix C) which have also been used to evaluate the model performance. Figure 4 shows the comparison of the seasonal cycle of model PAN mixing ratios with the surface measurements for a series of locations. The modelled PAN does not exhibit a clear seasonal correlation for most of the stations (Figure 4). The seasonality of PAN is found to be sensitive to temperature (through the thermal decomposition rate of PAN), $\mathrm{OH}$ mixing ratios and sunlight. However, PAN is long-lived with respect to reaction with $\mathrm{OH}$ or photolysis and its lifetime in the boundary layer is controlled by thermal decomposition and by transport and decomposition. During summer, the enhancement in the PAN formation rate would be expected because of the increased formation of $\mathrm{CH}_{3} \mathrm{CO}_{3}$ during the oxidation of VOCs by $\mathrm{OH}$. However, the accompanying increased temperature is also responsible for the rapid increase in the rate of thermal decomposition of PAN. These combined effects lead to larger PAN abundances either during spring or during summer, depending on the location and meteorological condition.

PAN abundances at $\mathrm{NH}$ stations are at a maximum during AprilMay-June due to higher photochemical production in the presence of VOC and sunlight when they have a longer thermal lifetime [77-78] and at a minimum during November-December-January because of
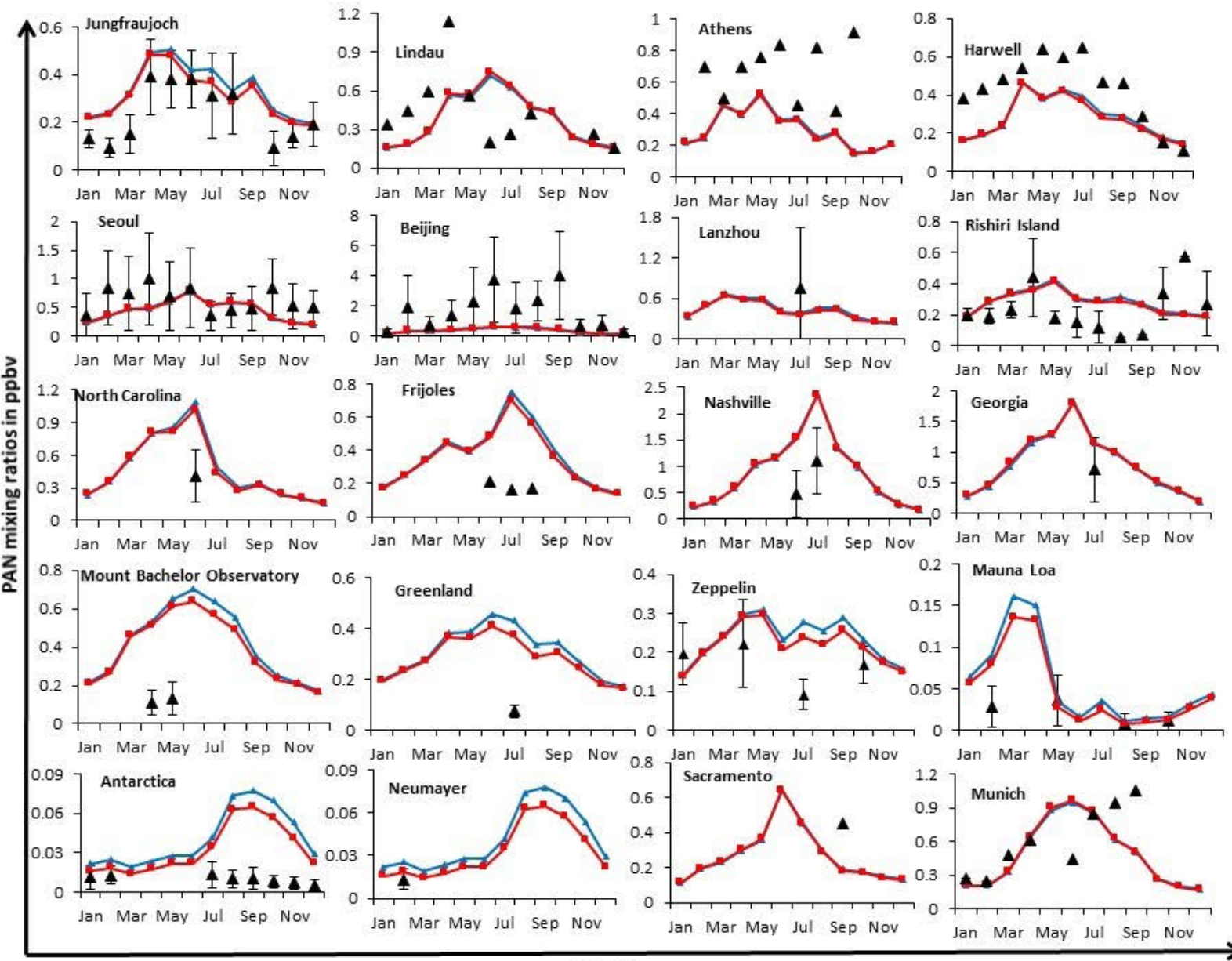

Month

Figure 4: Monthly variation of surface global PAN mixing ratios of selected monitoring stations. Blue and red lines represent mean calculated values of PAN produced by STOCHEM-base and STOCHEM-ISOP, respectively. Black triangles represent the measurement data and the black error bars represent measurement variability. 
Citation: Khan MAH, Cooke MC, Utembe SR, Archibald AT, Derwent RG, et al. (2017) Global Budget and Distribution of Peroxyacetyl Nitrate (PAN) for Present and Preindustrial Scenarios. Int J Earth Environ Sci 2: 130. doi: https://doi.org/10.15344/2456-351X/2017/130

Page 6 of 10

the lower photochemical production rate from $\mathrm{CH}_{3} \mathrm{CO}_{3}$ and $\mathrm{NO}_{2}$ The medium to long-range transportation of polluted air masses from the European boundary layer at European stations (e.g. Jungfraujoch, Lindau, Harwell, Munich, and Athens) resulted in a maximum model PAN in spring, which is consistent with the measurement data. The abundances of both model and measured PAN at Asian stations (e.g. Seoul, Beijing, Lanzhou, and Rishiri Island) during July-August are found to be lower than expected because of the significant thermal decomposition of PAN during these months. The model produces less PAN over East Asia (e.g. Beijing, Lanzhou, and Seoul) because of using limited anthropogenic aromatic emissions in STOCHEM-CRI Fischer et al. [56] performed a simulation with inclusion of emissions of aromatic species and found that the aromatics can account for $30 \%$ of the PAN in the Asian outflow region. The overestimation of model data compared with measurement data is found for most of the US stations (e.g. North Carolina, Frijoles, Nashville, Georgia, and Mount Bachelor Observatory) and also Greenland could be due to the overprediction of model $\mathrm{NO}_{x}$ emissions and $\mathrm{CH}_{3} \mathrm{CO}_{3}$ formation.

Both the model and surface PAN observations indicate that the springtime maximum is pronounced at Zeppelin Mountain near NyÅlesund, Svalbard which is due to long range transport of pollutants from northern mid-latitudes sources [12,36]. During summer, the maximum thermal decomposition of PAN at Zeppelin Mountain occurs [36] and the transport of midlatitude air into high northern latitudes is likely [79] which resulted in the summer minimum. During fall, the transport and temperature favours higher PAN levels at Zeppelin Mountain, but during winter, the photochemical production of PAN is reduced due to the lack of sunlight in midlatitudes [36].

a)

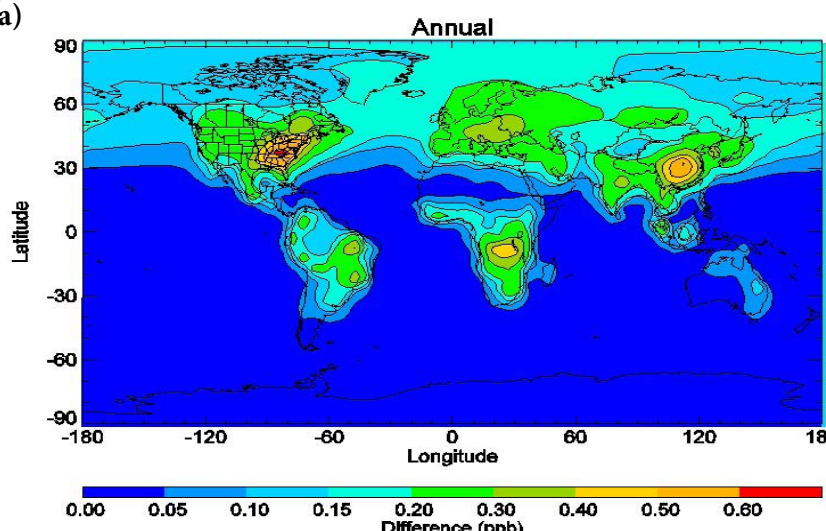

c)

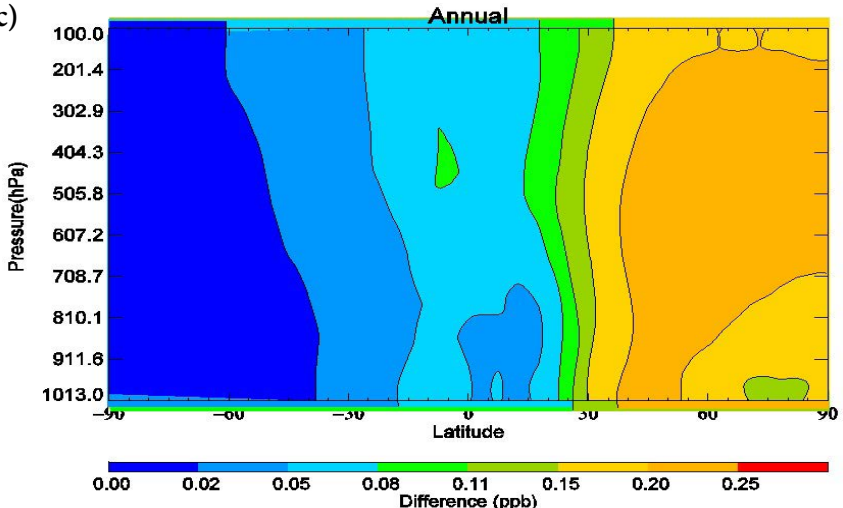

The SH stations (e.g. coastal Antarctica, Neumayer, and Santiago) show an analogous seasonal trend with maximum and minimum mixing ratios found in spring (September-October) and winter seasons (December-January-February). The surface PAN mixing ratios in Antarctica (e.g. coastal Antarctica and Neumayer) is found to be lower than that in the Arctic because the larger distance from other continents makes the transport of PAN or its precursors to Antarctica less effective.

\section{Preindustrial scenario and implication of $\mathrm{HO}_{\mathrm{x}}$ recycling}

The relative changes of surface mixing ratios of PAN (up to 0.6 $\mathrm{ppb}$ ) from preindustrial to present day scenarios are found in the $\mathrm{NH}$ in between $30^{\circ} \mathrm{N}$ and $60^{\circ} \mathrm{N}$ due to greater anthropogenic sources of $\mathrm{NO}_{x}$ and VOCs in the present day scenario (Figures $5 \mathrm{a}$ and $5 \mathrm{c}$ ). The percentage change results show that the mean surface PAN mixing ratios have increased since preindustrial times by $400 \%$ in the most of the $\mathrm{NH}$ surface (maximum changes of up to $1500 \%$ near the equator remote region) and by $100 \%$ in the SH. Mixing ratios in the upper troposphere have increased by $400-600 \%$ largely in between $20^{\circ} \mathrm{N}$ to $35^{\circ} \mathrm{N}$. The percentage changes decline with altitude and are smaller away from the strong anthropogenic source region (Figures $5 \mathrm{~b}$ and $5 \mathrm{~d}$ ). The increased PAN in the present day scenario contribute significantly to the total reactive nitrogen $\left(\mathrm{NO}_{\mathrm{y}}\right)$ budget in the troposphere, especially in the $\mathrm{NH}$. The global burden of PAN has increased from $220 \mathrm{Gg}(\mathrm{N})$ in CRI1800 to $398 \mathrm{Gg}(\mathrm{N})$ in the base simulation, which is an increase of $81 \%$.

The importance of the $\mathrm{HO}_{x}$ recycling mechanisms with reference to oxygenated peroxy radicals is caused by an increase in $\mathrm{HO}_{\mathrm{x}}$ levels
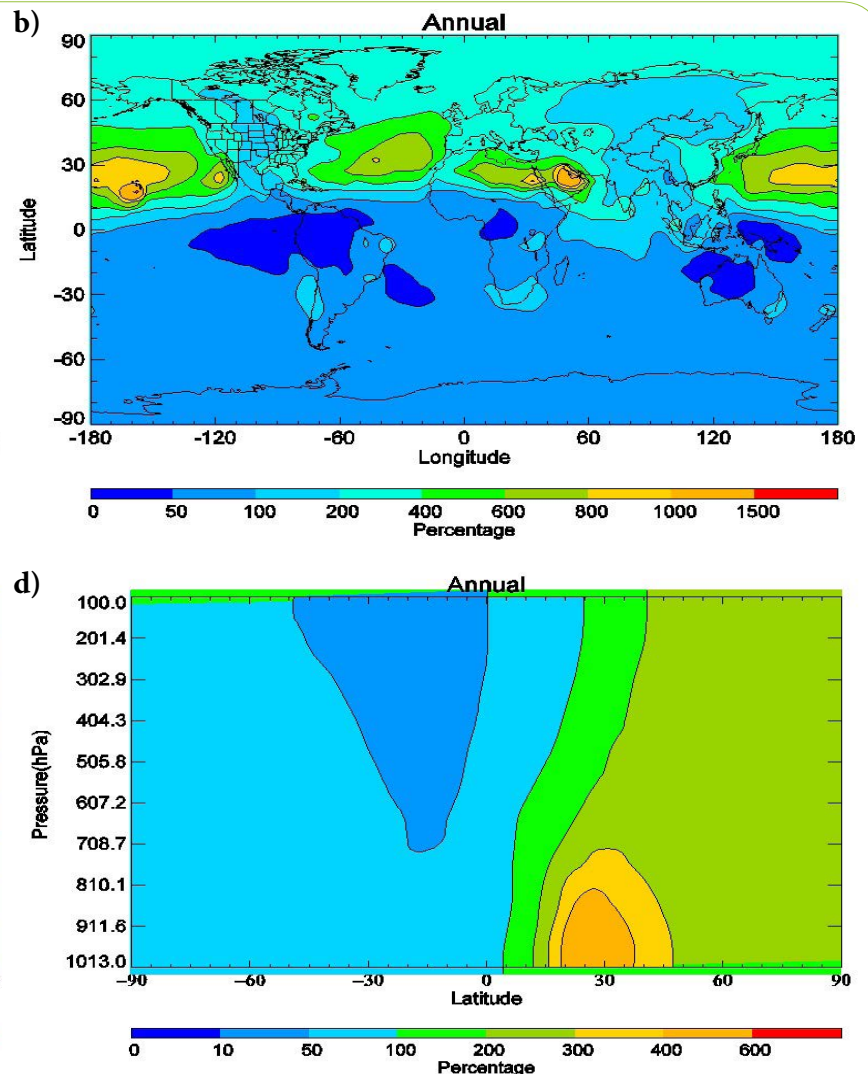

Figure 5: (a) The surface annual PAN difference between present and preindustrial day (b) The percent change of surface annual PAN from preindustrial to present day for PAN, (c) The zonal annual PAN difference between present and preindustrial day (d) The percent change of zonal annual PAN from preindustrial to present day for PAN [Note: Percentage change $\left.=\left((\text { Base-B1800 })^{\star} 100\right) / \mathrm{B} 1800\right]$. 
Citation: Khan MAH, Cooke MC, Utembe SR, Archibald AT, Derwent RG, et al. (2017) Global Budget and Distribution of Peroxyacetyl Nitrate (PAN) for Present and Preindustrial Scenarios. Int J Earth Environ Sci 2: 130. doi: https://doi.org/10.15344/2456-351X/2017/130

Page 7 of 10

by up to $60 \%$ over land (Figure 6a). The increased $\mathrm{OH}$ from isoprene recycling has a greater effect than the decreased $\mathrm{OH}$ production from the oxygenated peroxy radicals with an increment of $\mathrm{OH}$ global burden by $5 \%$. A decrease in $\mathrm{NO}_{\mathrm{x}}$ for ISOP-1800 relative to B-1800 is found over most of the areas with the largest percentage changes (up to $25 \%$ decrease) over the remote oceanic regions (Figure 6b), only two areas (e.g. Amazon and South-East Asia) in where the annual mean $\mathrm{NO}_{x}$ are increased by up to $2 \%$ because of the increased biomass burning and vegetation $\mathrm{NO}_{\mathrm{x}}$ emissions from the Amazon and anthropogenic $\mathrm{NO}_{x}$ emissions from South-East Asia. The isoprene concentrations in South-East Asia are lower than that in Amazon [69], but the large change in $\mathrm{NO}_{\mathrm{x}}$ for South-East Asia has led to a much more significant
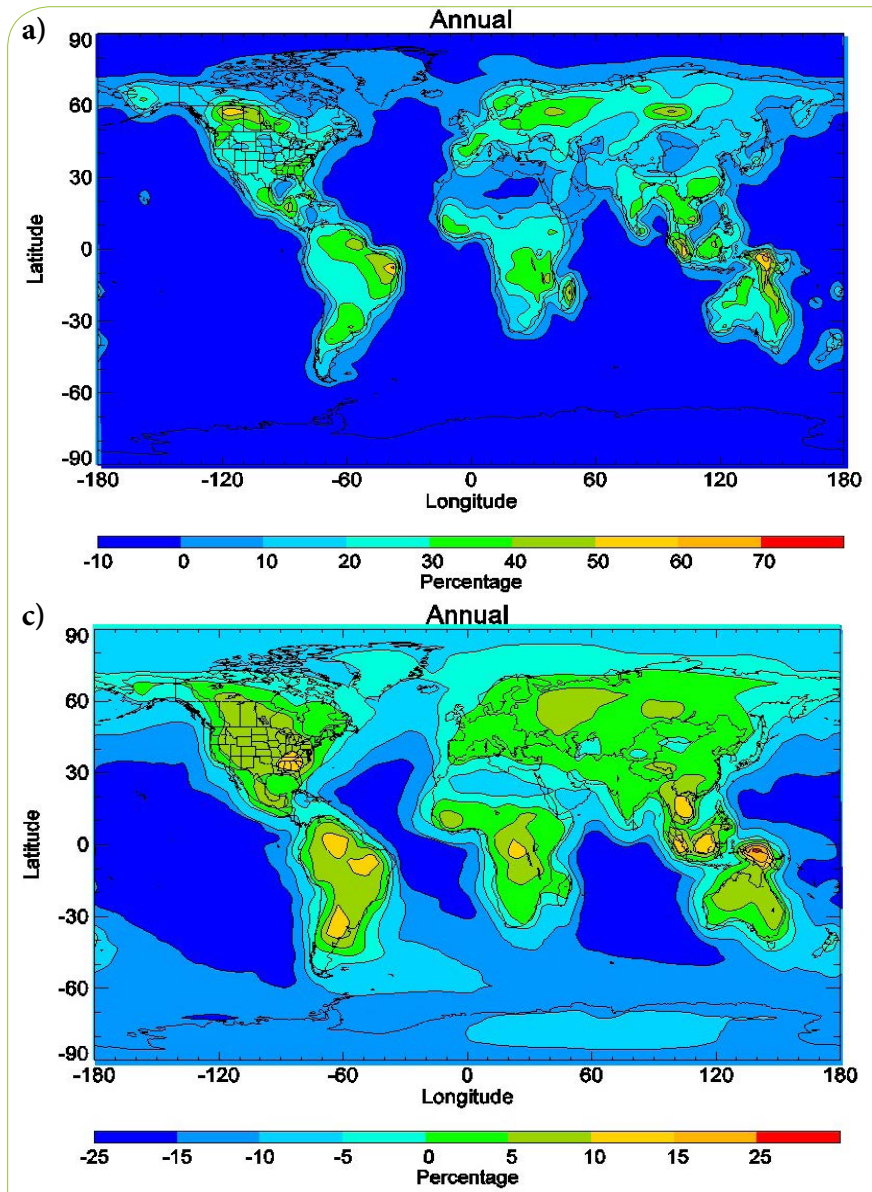

d)

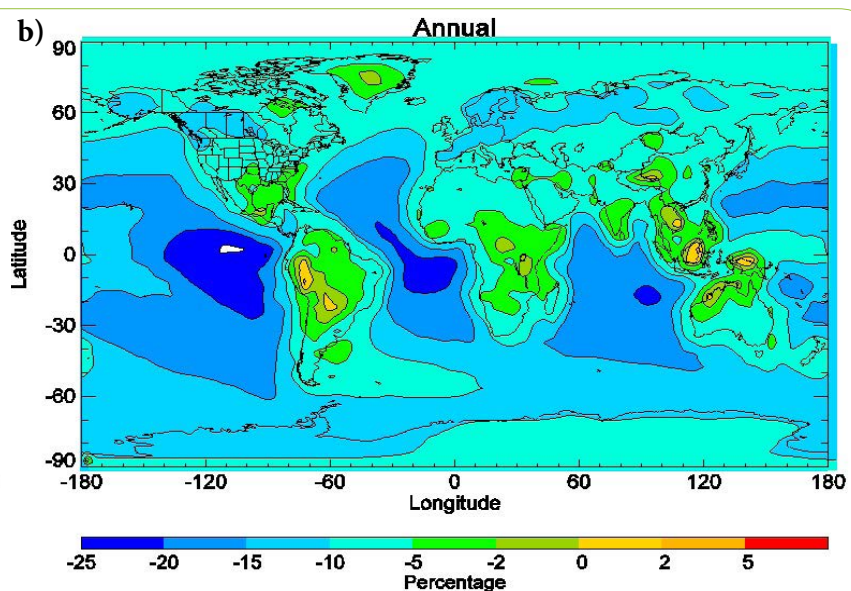

effect of the recycling chemistry in this region. This highlights the important balance between isoprene emissions and $\mathrm{NO}_{\mathrm{x}}$ levels.

$\mathrm{HO}_{\mathrm{x}}$ recycling occurs at low $\mathrm{NO}_{\mathrm{x}}$ levels and thus removing the $\mathrm{NO}_{\mathrm{x}}$ from anthropogenic sources in the preindustrial scenario makes the recycling more efficient. The inclusion of $\mathrm{HO}_{x}$ recycling leads to a decrease in PAN (Figure 6d) and an increase in $\mathrm{HNO}_{3}$ formation over emission regions (Figure $6 \mathrm{c}$ ). $\mathrm{HNO}_{3}$ is rapidly deposited over land and its removal leads to reduced global levels of gaseous oxidised nitrogen species (e.g. PAN) which leads to less oxidised nitrogen being transported to remote regions and thus the largest percentage changes in $\mathrm{NO}_{\mathrm{x}}$ are observed over the remote oceanic regions (Figure 6b).

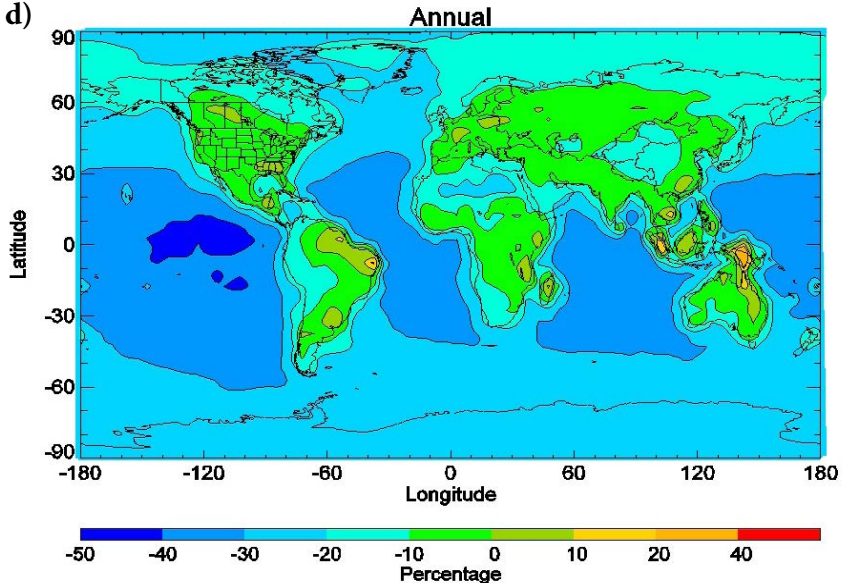

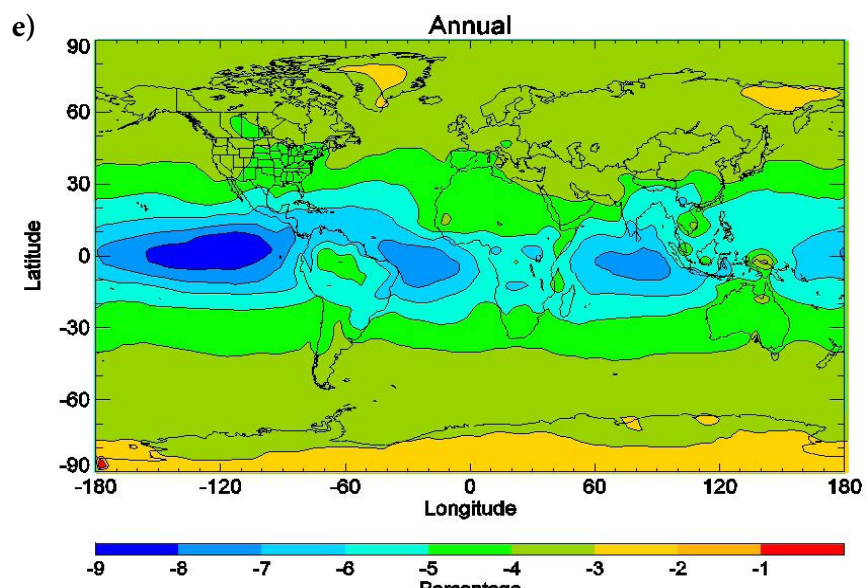

Figure 6: The surface and annual mean percentage changes from B1800 to ISOP1800 for (a) $\mathrm{HO}_{\mathrm{x}^{\prime}}$ (b) $\mathrm{NO}_{\mathrm{x}^{\prime}}$, (c) $\mathrm{HNO}_{3}$, (d) PAN, (e) $\mathrm{O}_{3}$ [Note: Percentage change $\left.=\left((\mathrm{ISOP} 1800-\mathrm{B} 1800)^{*} 100\right) / \mathrm{B} 1800\right]$. 
Citation: Khan MAH, Cooke MC, Utembe SR, Archibald AT, Derwent RG, et al. (2017) Global Budget and Distribution of Peroxyacetyl Nitrate (PAN) for Present and Preindustrial Scenarios. Int J Earth Environ Sci 2: 130. doi: https://doi.org/10.15344/2456-351X/2017/130

Page 8 of 10

The changes in $\mathrm{O}_{3}$ are driven by the redistribution of $\mathrm{NO}_{x}$ which is found to be largest in remote oceanic regions (Figure 6e). The greatest percentage change (up to $9 \%$ decrease) in $\mathrm{O}_{3}$ concentration is found at the surface in equatorial regions upon including $\mathrm{HO}_{\mathrm{x}}$ recycling in the preindustrial scenario.

\section{Conclusion}

The complexity of the VOC degradation in STOCHEM-CRI resulted in an increase of tropospheric PAN which act as nitrogen reservoir species before releasing and transporting reactive nitrogen $\left(\mathrm{NO}_{\mathrm{x}}\right)$ away from the pollution centers. The increase in the level of PAN with altitude is consistent with reduced thermal decomposition in the upper troposphere. The overall comparison between measurements and simulations show that STOCHEM-CRI overpredicts the concentrations of PAN in the troposphere. The global burden of PAN for the present scenario is found to be $398 \mathrm{Gg}(\mathrm{N})$ and the inclusion of $\mathrm{HO}_{x}$ recycling reduces PAN by as much as $13 \%$, bringing the model into closer agreement with measured values. The globally averaged tropospheric lifetimes of PAN is found to be 9.3 hours. The abundance of PAN have been seen in the continental atmosphere, with mixing ratios up to $2.0 \mathrm{ppb}$ over the polluted regions of North America during J-J-A and up to $1.2 \mathrm{ppb}$ over the Amazon rainforest during D-J-F. The inclusion of $\mathrm{HO}_{x}$ recycling leads to a decrease of PAN by up to $40 \%$ over the oceans in the surface layers and by up to $10 \%$ in the low to middle tropospheric layer of equatorial regions (during J-J-A) and $\mathrm{SH}$ regions (during D-J-F) in a present scenario. The maximum percentage changes (up to $1500 \%$ ) from preindustrial to present scenarios for PAN are found near the equator remote region and the inclusion of $\mathrm{HO}_{\mathrm{x}}$ recycling in the preindustrial scenario can decrease $\mathrm{O}_{3}$ concentrations by up to $9 \%$.

\section{Competing Interests}

The authors declare that they have no competing interests.

\section{Acknowledgments}

ATA thanks GWR and the U.K. Met. Office for funding (studentship), MCC thanks EPSRC for a studentship, DES and CJP thank NERC and Bristol ChemLabS under whose auspices various aspects of this work was funded.

\section{References}

1. Finlayson-Pitts BJ, Pitts Jr JN (1986) Atmospheric Chemistry: Fundamental and Experimental Techniques. Wiley and Sons, New York.

2. Seinfeld JH (1986) Atmospheric Chemistry and Physics of Air Pollution Wiley and Sons, New York.

3. Stephens ER, Darley EF, Taylor OC, Scott WE (1961) Photochemical reaction products in air pollution. Int J Air Water Pollut 4: 79-100.

4. Sun EJ, Huang MH (1995) Detection of peroxyacetyl nitrate at phytotoxic levels and its effects on vegetation in Taiwan. Atmos Environ 29: 2899 2904.

5. Altshuller AP (1978) Assessment of the contribution of chemical species to the eye irritation potential of photochemical smog. J Air Pollut Contr Assoc 28: 594-598.

6. Wayne RP (2000) Chemistry of the atmospheres. 3rd Edn. Oxford Science publications. Clarendon Press, Oxford, UK, $337 \mathrm{pp}$

7. Crutzen PJ (1979) The role of $\mathrm{NO}$ and $\mathrm{NO}_{2}$ in the chemistry of the troposphere and stratosphere. Annu Rev Earth Planet Sci 7: 443-472.

8. Singh HB, Hanst PL (1981) Peroxyacetyl nitrate (PAN) in the unpolluted atmosphere: An important reservoir for nitrogen oxides. Geophys Res Lett 8: 941-944.
9. Singh HB (1987) Reactive nitrogen in the troposphere: Chemistry and transport of PAN. Environ Sci Technol 21: 320-327.

10. Ridley BA, Shetter JD, Walega JG, Madronich S, Elsworth CM, et al. (1990) The behavior of some organic nitrates at Boulder and Niwot Ridge, Colorado. J Geophys Res 95: 13949-13961.

11. Roberts JM, Tanner RL, Newman L, Bowersox VC, Bottenheim JW, et al (1995) Relationships between PAN and ozone at sites in eastern North America. J Geophys Res 100: 22821-22830.

12. Moxim WJ, Levy II H, Kasibhatla PS (1996) Simulated global tropospheric PAN: its transport and impact on NOx. J Geophys Res 101: 12621-12638.

13. Suppan P, Fabian P, Vyras L, Gryning SE (1998) The behaviour of ozone and peroxyacetyl nitrate concentrations for different wind regimes during the MEDCAPHOT-TRACE campaign in the greater area of Athens, Greece. Atmos Environ 32: 2089-2102.

14. Hudman RC, Jacob DJ, Cooper OR, Evans MJ, Heald CL, et al. (2004) Ozone production in transpacific Asian pollution plumes and implications for ozone air quality in California. J Geophys Res 109: D23S10.

15. Fischer EV, Jaffe DA, Reidmiller DR, Jaeglé $L$ (2010) Meteorological controls on observed peroxyacetyl nitrate at Mount Bachelor during the spring of 2008. J Geophys Res 115: D03302.

16. Roberts JM, Bertman SB (1992) The thermal decomposition of peroxyacetic nitric anhydride (PAN) and peroxymethacrylic nitric anhydride (MPAN). Int J Chem Kin 24: 297-307.

17. Bridier I, Caralp F, Loirat H, Lesclaux R, Veyret B, et al. (1991) Kinetic and theoretical studies of the reactions of acetylperoxy+nitrogen dioxide $+M$ acetyl peroxynitrate $+M$ between 248 and $393 \mathrm{~K}$ and between 30 and 760 torr. J Phys Chem 95: 3594-3600.

18. Orlando JJ, Tyndall GS, Calvert JG (1992) Thermal decomposition pathways for peroxyacetyl nitrate (PAN): Implications for atmospheric methyl nitrate levels. Atmos Environ 26: 3111-3118.

19. Cox RA, Roffey MJ (1977) Thermal decomposition of peroxyacetyl nitrate in the presence of nitric oxide. Environ Sci Technol 11: 900-906.

20. Talukdar RK, Burkholder JB, Schmoltner AM, Roberts JM, Wilson RR, et al. (1995) Investigation of the loss processes for peroxyacetyl nitrate in the atmosphere: UV photolysis and reaction with $\mathrm{OH}$. J Geophys Res Atmos 100: 14163-14173.

21. Tsalkani N, Mellouki A, POulet G, Toupance G, LeBras G (1988) Rate constant measurements for the reactions of $\mathrm{OH}$ and $\mathrm{Cl}$ with peroxyacetyl nitrate at $298 \mathrm{~K}$. J Atmos Chem 7: 409-419.

22. Kames J, Schweighoefer S, Schurath U (1991) Henry's law constant and hydrolysis of peroxyacetyl nitrate (PAN). J Atmos Chem 12: 169-180.

23. Kames J, Schurath U (1995) Henry's law and hydrolysis rate constants for peroxyacyl nitrates (PANs) using a homogeneous gas-phase source. $J$ Atmos Chem 21: 151-164.

24. Peake E, Maclean MA, Lester PF, Sandhu HS (1988) Peroxyacetylnitrate (PAN) in the atmosphere of Edmonton, Alberta, Canada. Atmos Environ 22: 973-981.

25. Gallagher MS, Carsey TP, Farmer ML (1990) Peroxyacetyl nitrate in the North Atlantic marine boundary layer. Global Biogeochem Cycles 4: 297308.

26. Muller KP, Rudolph J (1992) Measurements of peroxyacetylnitrate in the marine boundary layer over the Atlantic. J Atmos Chem 15: 361-367.

27. Singh HB, Condon E, Vedder J, O'Hara D, Ridley BA, et al. (1990) Peroxyacetyl nitrate measurements during CITE 2: Atmospheric distribution and precursor relationships. J Geophys Res 95: 10163-10178.

28. Singh HB, O'Hara D, Herlth D, Bradshaw JD, Sandholm ST, et al. (1992) Atmospheric measurements of peroxyacetyl nitrate and other organic nitrate at high latitudes: Possible sources and sinks. J Geophys Res 97: 16511-16522.

29. Walega JG, Ridley BA, Madronich S, Grahek FE, Shetter JD, et al. (1992) Observations of peroxyacetyl nitrate, peroxypropionyl nitrate, methyl nitrate and ozone during the Mauna Loa Observatory Photochemistry Experiment. J Geophys Res 97: 10311-10330. 
Citation: Khan MAH, Cooke MC, Utembe SR, Archibald AT, Derwent RG, et al. (2017) Global Budget and Distribution of Peroxyacetyl Nitrate (PAN) for Present and Preindustrial Scenarios. Int J Earth Environ Sci 2: 130. doi: https://doi.org/10.15344/2456-351X/2017/130

Page 9 of 10

30. Kourtidis KA, Fabian P, Zeefos C, Rappenglück B (1993) Peroxyacety nitrate (PAN), peroxypropionyl nitrate (PPN) and PAN/ozone ratio measurements at three sites in Germany. Tellus 45B: 442-457.

31. Rappenglück B, Kourtidis K, Fabian P (1993) Measurements of ozone and peroxyacetyl nitrate (PAN) in Munich. Atmos Environ 27: 293-305.

32. Gaffney JS, Marley NA, Prestbo EW (1993) Measurements of peroxyacetyl nitrate (PAN) at a remote site in the southwestern United States: Tropospheric implications. Environ Sci Technol 27: 1905-1910.

33. Gaffney JS, Marley NA, Cunningham MM, Doskey PV (1999) Measurements of peroxyacyl nitrates (PANs) in Mexico City: implications for megacity air quality impacts on regional scales. Atmos Environ 33: 5003-5012.

34. Hartsell BE, Aneja VP, Lonneman WA (1994) Relationships between peroxyacetyl nitrate, O3, and NOy at the rural Southern Oxidants study site in central Piedmont, North Carolina, site SONIA. J Geophys Res 99: 21033-21041.

35. Jacobi H-W, Schrems O (1999) Perosyacetyl nitrate (PAN) distribution over the South Atlantic Ocean. Phys Chem Chem Phys 1: 5517-5521.

36. Beine HJ, Krognes $T$ (2000) The seasonal cycle of peroxyacetyl nitrate (PAN) in the European Arctic. Atmos Environ 34: 933-940.

37. Jacobi HW, Weller R, Jones AE, Anderson PS, Schrems O (2000) Peroxyacetyl nitrate (PAN) concentrations in the Arctic troposphere measured during the photochemical experiment at Neumayer (PEAN'99). Atmos Environ 34: 5235-5247.

38. Grosjean E, Grosjean D, Woodhouse LF (2001) Peroxyacetyl nitrate and peroxypropionyl nitrate during SCOS 97-NARSTO. Environ Sci Technol 35 4007-4014.

39. Grosjean E, Grosjean D, Woodhouse LF, Yang YJ (2002) Peroxyacetyl nitrate and peroxypropionyl nitrate in Porto Alegre, Brazil. Atmos Environ 36: 2405-2419.

40. Ford KM, Campbell BM, Shepson PB, Bertman SB, Honrath RE, et al (2002) Studies of Peroxyacetyl nitrate (PAN) and its interaction with the snowpack at Summit, Greenland. J Geophys Res Atm 107: 4102.

41. Roberts JM, Flocke F, Chen G, de Gouw J, Holloway JS, et al. (2004) Measurement of peroxycarboxylic nitric anhydrides (PANs) during the ITCT 2K2 aircraft intensive experiment. J Geophys Res 109: D23S21.

42. Roberts JM, Marchewka M, Bertman SB, Sommariva R, Warneke C, et al (2007) Measurements of PANs during the New England Air Quality Study 2002. J Geophys Res 112: D20306.

43. Coheur PF, Herbin H, Clerbaux C, Hurtmans D, Wespes C, et al. (2007) ACE-FTS observation of a young biomass burning plume: first reported measurements of $\mathrm{C} 2 \mathrm{H} 4, \mathrm{C} 3 \mathrm{H} 6 \mathrm{O}, \mathrm{H} 2 \mathrm{CO}$ and $\mathrm{PAN}$ by infrared occultation from space. Atmos Chem Phys 7: 5437-5446.

44. Glatthor N, von Clarmann T, Fischer H, Funke B, Grabowski U, et al. (2007) Global peroxyacetyl nitrate (PAN) retrieval in the upper troposphere from limb emission spectra of the Michelson Interferometer for Passive Atmospheric Sounding (MIPAS). Atmos Chem Phys 7: 2775-2787.

45. Marley NA, Gaffney JS, Ramos-Villegas R, González BC (2007) Comparison of measurements of peroxyacyl nitrates and primary carbonaceous aerosol concentrations in Mexico City determined in 1997 and 2003. Atmos Chem Phys 7: 2277-2285.

46. Lee G, Jang Y, Lee H, Han JS, Kim KR, Lee M (2008) Characteristic behaviour of peroxyacetyl nitrate (PAN) in Seoul megacity, Korea. Chemosphere 73: 619-628.

47. Zhang JM, Wang T, Ding AJ, Zhou XH, Xue LK, et al. (2009) Continuous measurement of peroxyacetyl nitrate (PAN) in suburban and remote areas of western China. Atmos Environ 43: 228-237.

48. Liu Z, Wang Y, Gu D, Zhao C, Huey LG, et al. (2010) Evidence of reactive aromatics as a major source of peroxy acetyl nitrate over China. Environ Sci Technol 44: 7017-7022.

49. Moore DP, Remedios JJ (2010) Seasonality of Peroxyacetyl nitrate (PAN) in the upper troposphere and lower stratosphere using the MIPAS-E instrument. Atmos Chem Phys 10: 6117-6128.

50. Lee JB, Yoon JS, Jung K, Eom SW, Chae YZ, et al. (2013) Peroxyacetyl nitrate (PAN) in the urban atmosphere. Chemosphere 93: 1796-1803.

51. Phillips GJ, Pouvesle N, Thieser J, Schuster G, Axinte R, et al. (2013) Peroxyacetyl nitrate (PAN) and peroxyacetic acid (PAA) measurements by iodide chemical ionisation mass spectrometry: first analysis of results in the boreal forest and implications for the measurement of PAN fluxes. Atmos Chem Phys 13: 1129-1139.
52. Tereszchuk KA, Moore DP, Harrison JJ, Boone CD, Park M, et al. (2013) Observations of peroxyacetyl nitrate (PAN) in the upper troposphere by the Atmospheric Chemistry Experiment-Fourier Transform Spectrometer (ACE-FTS). Atmos Chem Phys 13: 5601-5613

53. Zhang G, Mu Y, Liu J, Zhang C, Zhang Y, et al. (2014) Seasonal and diurnal variations of atmospheric peroxyacetyl nitrate, peroxypropionyl nitrate, and carbon tetrachloride in Beijing. J Environ Sci(china) 26: 65-74

54. Emmons LK, Hauglustaine DA, Müller JF, Carroll MA, Brasseur GP, et al (2000) Data composites of airborne observations of tropospheric ozone and its precursors. J Geophys Res 105: 20497-20538.

55. Horowitz LW, Walters S, Mauzerall DL, Emmons LK, Rasch PJ, et al. (2003) A global simulation of tropospheric ozone and related tracers: Description and evaluation of MOZART, version 2. J Geophys Res 108: 4784.

56. Fischer EV, Jacob DJ, Yantosca RM, Sulprizio MP, Millet DB, et al. (2014) Atmospheric peroxyacetyl nitrate (PAN): a global budget and source attribution. Atmos Chem Phys 14: 2679-2698.

57. Peeters J, Nguyen TL, Vereecken L (2009) HOx radical regeneration in the oxidation of isoprene. Phys Chem Chem Phys 11: 5935-5939.

58. Hasson AS, Tyndall GS, Orlando JJ, Singh S, Hernandez SQ, et al. (2012) Branching ratios for the reaction of selected carbonyl-containing peroxy radicals with hydroperoxy radicals. J Phys Chem A 116: 6264-6281.

59. Collins WJ, Stevenson DS, Johnson CE, Derwent RG (1997) Tropospheric ozone in a Global-Scale Three-Dimensional Lagrangian Model and its response to NOx emission controls. J Atmos Chem 26: 223-274.

60. Utembe SR, Cooke MC, Archibald AT, Jenkin ME, Derwent RG, Shallcross DE (2010) Using a reduced Common Representative Intermediates (CR v2-R5) mechanism to simulate tropospheric ozone in a 3-D Lagrangian chemistry transport model. Atmos Environ 13: 1609-1622.

61. Derwent RG, Stevenson DS, Doherty RM, Collins WJ, Sanderson MG (2008) How is surface ozone in Europe linked to Asian and North American NOx emissions? Atmos Environ 42: 7412-7422.

62. Cooke MC (2010) Global modelling of atmospheric trace gases using the CRI mechanism. PhD Thesis, University of Bristol, UK.

63. Watson LA (2007) Development and application of chemical mechanisms in atmospheric modelling. PhD thesis, University of Bristol, UK.

64. Watson LA, Shallcross DE, Utembe SR, Jenkin ME (2008) A Common Representative Intermediate (CRI) mechanism for VOC degradation. Part 2: gas phase mechanism reduction. Atmos Environ 42: 7196-7204.

65. Jenkin ME, Watson LA, Utembe SR, Shallcross DE (2008) A Common Representative Intermediate (CRI) mechanism for VOC degradation. Part1: gas phase mechanism development. Atmos Environ 42: 7185-7195.

66. Utembe SR, Watson LA, Shallcross DE, Jenkin ME (2009) A Common Representative Intermediates (CRI) mechanism for VOC degradation. Part 3: Development of a secondary organic aerosol module. Atmos Environ 43: 1982-1990.

67. Granier C, Lamarque JF, Mieville A, Muller JF, Olivier J, et al. (2005) POET, a database of surface emissions of ozone precursors.

68. Khan MAH, Cooke MC, Utembe SR, Xiao P, Derwent RG, et al. (2014) Reassessing the photochemical production of methanol from peroxy radical self and cross reactions using the STOCHEM-CRI global chemistry and transport model. Atmos Environ 99: 77-84.

69. Archibald AT, Cooke MC, Utembe SR, Shallcross DE, Derwent RG, et al (2010) Impacts of mechanistic changes on HOx formation and recycling in the oxidation of isoprene. Atmos Chem Phys 10: 8097-8118.

70. Peeters J, Müller J-F, Stavrakou T, Nguyen VS (2014) Hydroxyl radical recycling in isoprene oxidation driven by hydrogen bonding and hydrogen tunneling: The upgraded LIM1 mechanism. J Phys Chem A 118: 86258643.

71. Khan MAH, Cooke MC, Utembe SR, Archibald AT, Derwent RG, et al (2015) Global modelling of the nitrate radical (NO3) for present and preindustrial scenarios. Atmos Res 164-165: 347-357.

72. Lelieveld J, Butler TM, Crowley JN, Dillon TJ, Fischer H, et al. (2008) Atmospheric oxidation capacity sustained by a tropical forest. Nature 452 737-740.

73. Pugh TAM, MacKenzie AR, Hewitt CN, Langford B, Edwards PM, et al (2010) Simulating atmospheric composition over a south-east Asian tropical rainforest: performance of a chemistry box model. Atmos Chem Phys 10: 279-298.
Int J Earth Environ Sci

ISSN: $2456-351 \mathrm{X}$
IJEES, an open access journal

Volume 2. 2017. 130 
Citation: Khan MAH, Cooke MC, Utembe SR, Archibald AT, Derwent RG, et al. (2017) Global Budget and Distribution of Peroxyacetyl Nitrate (PAN) for Present and Preindustrial Scenarios. Int J Earth Environ Sci 2: 130. doi: https://doi.org/10.15344/2456-351X/2017/130

Page 10 of 10

74. Canosa-Mas CE, King MD, Lopez R, Percival CJ, Wayne RP, et al. (1996) Is the reaction between $\mathrm{CH} 3 \mathrm{C}(\mathrm{O}) \mathrm{O} 2$ and $\mathrm{NO} 3$ important in the night-time troposphere? J Chem Soc Faraday Trans 92: 2211-2222.

75. von Kuhlmann R, Lawrence MG, Crutzen PJ (2003) A model for studies of tropospheric ozone and nonmethane hydrocarbons: Model evaluation of ozone-related species. J Geophys Res 108: 4729.

76. Khan MAH, Cooke MC, Utembe SR, Xiao P, Morris WC, et al. (2015) The global budgets of organic hydroperoxides for present and pre-industrial scenarios. Atmos Environ 110: 65-74.

77. Brice KA, Bottenheim JW, Anlauf KG, Wiebe HA (1988) Long-term measurements of atmospheric peroxyacetylnitrate (PAN) at rural sites in Ontario and Nova Scotia; seasonal variations and long-range transport. Tellus B 40: 408-425.

78. Penkett SA, Brice KA (1986) The spring maximum in photooxidants in the Northern Hemisphere troposphere. Nature 319: 655-657.

79. Iversen T (1993) Meteorology and transport of air masses in Arctic regions In: Niki H, Becker KH (Eds.). The tropospheric chemistry of ozone in the polar regions NATO ASI series 17. Springer Berlin, pp. 57-75. 